\title{
PENGETAHUAN DAN PERSEPSI POLITIK PADA REMAJA
}

\author{
Putri Limilia* \& Evie Ariadne \\ Fakultas IImu Komunikasi, Universitas Padjadjaran, Bandung \\ *Email: p.limilia@unpad.ac.id
}

\begin{abstract}
Abstrak
Penelitian ini mengkaji tentang tingkat pengetahuan dan persepsi pemilih pemula terhadap partai politik. Hal ini penting dilakukan karena pengetahuan dan persepsi politik merupakan faktor-faktor yang berperan penting dalam memahami partisipasi politik. Secara praktis, penelitian ini juga penting untuk dilakukan karenapemilih pemula memiliki peranan penting dalam demokrasi dan disaat bersamaan memiliki partisipasi dan ketertarikan politik yang rendah. Oleh karena itu, pada penelitian ini, peneliti berupaya untuk memahami pengetahuan dan persepsi poltik remaja. Secara spesifik, penelitik mengkaji pengetahuan dan persepsi terhadap partai politik sebagai salah satu institutasi politik. Metode yang digunakan adalah kualitatif dengan desain penelitian studi kasus. Teknik pengambilan data yang digunakan adalah wawancara. Partisipan penelitian ini adalah 20 orang siswa sekolah menengah atas yang berusia 16 hingga 18 tahun dan belum pernah memilih. Hasil penelitian menunjukkan bahwa pemilih pemula memiliki pengetahuan yang rendah tentang konsep, peran, dan fungsi partai politik. Rendahnya tingkat pengetahuan tersebut diiringi dengan persepsi negatif terhadap partai politik. Pemilih pemula mempersepsikan secara negatif parpol sebagai organisasi yang hanya mementingkan diri sendiri, korupsi, dan hanya melakukan pencitraan.
\end{abstract}

Kata kunci: partai politik; pemilih pemula; persepsi; pengetahuan

\begin{abstract}
This paper examined political knowledge and perception among young and first-time voters. This research is important because political knowledge and perception are two factors that has be known for its ability to drive political participation. Practically, this also because young and first time voters have essential roles in democracy but at the same time, they have lack of interests in politics. Thus, in present study we seek to understand political knowledge and perception of tenagers. We particularly examined their knowledge and perception on political party as one of political institutions. We employed qualitative methods with case study design and use interview to collect the data. 20 senior high school students were employed as participants. Their age ranged from 16 to 18 years old and no voting experience previously. The result ssows the participants had low level of knowledge about concept, roles, and function of political parties. Further, we also found that the participants had negative perception about political parties. They perceived political parties as a corrupt organization and frequently doing superficial impression management conducts, and also selfish.
\end{abstract}

Keywords: political parties; first elector; perception; knowledge

\section{Pendahuluan}

Remaja sering diasumsikan sebagai individu yang tidak memiliki minat terhadap politik. Di usia yang relatif muda, remaja lebih tertarik kepada isu-isu yang lebih dekat dengan kesehariannya dibanding- 
kan dengan isu politik atau ekonomi. Remaja berpendapat bahwa isu politik atau ekonomi sangat membosankan dan begitu serius. Selain itu, isu tersebut tidak mendatangkan manfaat langsung bagi kehidupan mereka. Ketidaktertarikan remaja kepada politik juga diiringi dengan rendahnya kesadaran mereka akan tugas dan tanggungjawab sebagai pemilih pemula. Remaja melihat tanggungjawab sebagai pemilih pemula hanya sebatas datang ke tempat pemilihan suara (TPS) untuk kemudian memilih salah satu kandidat atau partai politik. Padahal, kegiatan tersebut tidak hanya sebatas ritual mencontreng. Ada makna dan dampak yang sangat besar dibalik ritual tersebut.

Komisi Pemilihan Umum (KPU) mendefinisikan pemilih pemula sebagai pemilih yang baru pertama kali menggunakan hak pilihnya. Pemilih tersebut biasanya berasal dari pemilih berusia 17 tahun. Data KPU juga menunjukkan bahwa pada tahun 2014 terdapat 14 juta pemilih pemula. Jumlah ini cukup besar bila dibandingkan dengan jumlah pemilih secara keseluruhan. Banyaknya jumlah pemilih pemula ini lah yang seharusnya disadari oleh mereka bahwa pemilu bukan sekedar ritual. Dengan jumlah yang banyak, mereka dapat membuat perubahan di negara ini.

Namun, pemilih pemula cenderung tidak begitu menyadari akan peran dan kekuatan yang mereka miliki. Sehingga, banyak politisi atau partai politik (parpol) yang memanfaatkan mereka. Hal ini ditambah lagi dengan karakter mereka yang labil secara emosional dan dapat dengan mudah dipengaruhi. Oleh karena itu, tidak jarang parpol atau politisi memanfaatkan kesempatan ini untuk memobilisasi mereka.

Permasalahan lain yang juga ditemukan pada pemilih pemula adalah rendahnya partisipasi politik. Pirie dan Worcester (2000) menyebutkan bahwa remaja di Inggris saat ini tidak banyak terlibat dalam politik bila dibandingkan dengan remaja 30 tahun yang lalu
(O'Toole, Lister, Marsh, Jones, \& McDonagh, 2003). Selain itu, Pirie dan Worcester juga menemukan bahwa remaja zaman sekarang juga dinilai memiliki pengetahun politik yang lebih rendah. Sebelum lebih jauh membahas mengenai faktor yang menyebabkan rendahnya partipasi politik remaja, ada baiknya kita mendefinisikan terlebih dahulu konsep partisipasi politik.

Masyarakat umum mendefinisikan partisipasi politik terbatas hanya pada keikutsertaan dalam pemilu. Hal ini karena media selalu meggunakan kata "partisipasi politik" hanya pada saat pemilu. Sementara itu, ilmuan memiliki pemahaman yang berbeda mengenai partisipasi politik. Parry, Moyser, dan Day (1992) mendefinisikan partisipasi politik sebagai keikutsertaan dalam pembuatan, mensosialisasikan, dan mengimplementasikan kebijakan tertentu (O'Toole dkk., 2003). Lebih lanjut, mereka menjabarkan beberapa bentuk partisipasi politik yaitu memilih dalam pemilu, menjadi anggota parpol, bergabung dengan kelompok tertentu, menandatangani petisi, atau berdemonstrasi.

Sementara itu, Education Audiovisual and Culture Executive Agency (EACEA) mengartikan partisipasi politik sebagai adanya ketertarikan dalam membangun opini dan bertindak untuk membuat perubahan di masyarakat (MedNet, 2014). Definisi tersebut diturunkan ke dalam empat bentuk partisipasi politik, yaitu: 1) partisipasi dalam demokrasi (mengikuti pemilu dan menjadi anggota parpol); 2) partisipasi dalam bentuk bergabung dengan lembaga nirlaba; 3) partisipasi dalam diskusi politik (menulis di media); 4) partisipasi dalam pencarian informasi atau pembelajaran tentang demokrasi (training atau seminar).

Kedua definisi tersebut memberikan gambaran bahwa partisipasi politik merupakan suatu konsep yang luas dengan turunan kegiatan yang tidak hanya terbatas kepada keikutsertaan dalam pemilu. Partisipasi politik juga dapat berupa keikutsertaan dalam seminar/training tentang 
demokrasi, menulis di media tentang isuisu politik, ikut serta dalam demonstrasi, dan lain-lain.

Rendahnya partisipasi politik pemilih pemula, dalam hal ini remaja, dapat dilihat dari partisipasi pada kegiatan-kegiatan di luar pemilu. Misalnya saja remaja dengan berpartisipasi dalam seminar/training, kampanye, diskusi politik, dan lain-lain. Penelitian yang dilakukan oleh Hidayah, Gunawan, dan Budiman (2017) dapat dijadikan sebagai contoh rendahnya partisipasi tersebut. Hasil peneltian mereka menunjukkan bahwa remaja di Kutai Kartanegara enggan berpartisipasi dalam kegiatan kampanye dan diskusi politik yang diselenggaran menjelang pilkada. Akan tetapi, remaja sangat tertarik berpartipasi dalam pilkada dengan tingkat partisipasi di tiga kelurahan di atas $60 \%$. Penelitian yang dilakukan oleh Suprojo (2013) juga menunjukkan bahwa remaja di kota Malang menemukan bahwa remaja memiliki sikap skeptis terhadap politik. Sikap ini muncul akibat media yang selalu menampilkan pemberitaan negatif seputar politik. Politik selalu diidentikkan dengan perebutan kekuasaan dan saling menjatuhkan (Suprojo, 2013). Pada akhirnya, sikap skeptis menyebabkan remaja tidak berpartisipasi dalam politik.

Berbagai penelitian menjelaskan bahwa ada beberapa faktor yang menyebabkan remaja enggan berpartisipasi dalam politik. Salah satunya adalah penelitian yang dilakukan oleh Henn, Weinstein, dan Forrest (2005). Mereka menemukan bahwa remaja tidak memiliki ketertarikan terhadap politik dan berpendapat bahwa politisi dan partai tidak bisa menjawab permasalahan bangsa (Henn dkk., 2005). Dengan kata lain, penelitian tersebut menunjukkan ada-nya persepsi negatif tentang manfaat politik dan sistem politik memiliki peranan dalam menurunkan partisipasi politik. Sejalan dengan Henn dkk; Pirie dan Worcester (2000) berpendapat bahwa rendahnya partisipasi politik remaja disebabkan oleh dua buah faktor yaitu, tidak adanya keuntungan yang didapat dengan berpartisipasi dan sikap individualis. Pada masa remaja, individu cenderung berorientasi kepada dirinya sendiri. Sehingga, setiap sikap atau tindakan yang dilakukan harus memberikan keuntungan secara pribadi, begitu juga dalam kaitannya dengan politik.

Tamanna (2018) menyebutkan sebagai negara yang juga baru dalam sistem demokrasi, Bangladesh juga menghadapi hal yang sama, yaitu rendahnya partisipasi politik remaja. Di dalam penelitiannya, Tamanna menemukan bahwa ada beberapa faktor yang menjadi pendorong rendahnya partisipasi tersebut, yaitu: 1) remaja tidak memiliki akses ke politik, politisi, dan pemerintahan; 2) remaja tidak dapat merasakan manfaat langsung dari politk; 3) tidak adanya kedekatan antara politisi/parpol dengan remaja karena ketidaadaan interaksi diantara keduanya; 4) remaja yang memandang bahwa politisi tidak memiliki pengetahuan atau kepemimpinan yang baik.

Berdasarkan dua pendapat di atas, kita mengetahui bahwa ada dua poin besar yang menyebabkan remaja enggan berpartisipasi dalam politik yaitu ketidakadaan manfaat yang didapat dan citra negatif politik. Politik, di masyarakat, memiliki citra sebagai ranah yang kotor dan kejam karena banyak sekali politis yang terlibat kasus korupsi, politik uang, dan nepotisme. Bergerak dari studi-studi sebelumnya tersebut, pada penelitian ini peneliti mencoba untuk memahami persepsi remaja tentang politik, khususnya partai politik. Berdasarkan studi sebelumnya diketahui bahwa persepsi tentang politik menjadi penting yang mengarahkan individu, dalam hal ini remaja, berpartisipasi dalam politik.

Peneliti memfokuskan persepsi ter hadap partai politik bergerak dari temuantemuan saat ini yang menunjukkan ada nya rasa tidak percaya yang cukup kuat terhadap anggota dan badan legislative. Hasil survei yang dilakukan oleh Lingkar Survei Indonesia (LSI), misalnya, me nemukan bahwa pada awal tahun 2015 tingkat kepercayaan masyarakat terhadap 
partai politik berkisar 50\% (Hanan, 2015). Kepercayaan tersebut lebih rendah dibandingkan dengan kepercayaan masyarakat terhadap presiden, KPK, dan TNI dengan rata-rata tingkat kepercayaan di atas $80 \%$. Survei yang dilakukan oleh LSI juga menemukan bahwa masyarakat memiliki pandangan negatif terhadap parpol. Masyarakat berpendapat bahwa parpol hanya mementikan kepentingan pribadi, tidak menepati janji, dan hanya berbicara tentang diri sendiri (Hanan, 2015).

Citra negatif pada parpol sangat mengkhawatirkan karena dapat menimbulkan sikap apatis masyarakat terhadap parpol. Pada akhirnya, sikap tersebut membuat masyarakat tidak lagi memiliki keinginan bergabung dalam parpol. Padahal, parpol merupakan salah satu bagian terpenting dalam menciptakan negara demokratis. Ada beberapa faktor yang menyebabkan masyarakat memiliki persepsi negatif terhadap parpol, yaitu kebohongan, korupsi, tidak memiliki kepedulian terhadap sesama, tidak memiliki kompetensi, tersangkut kasus tertentu, penyalahgunaan kekuasaan, tidak bekerja keras, dan tidak transparan (Haryanto dkk., 2015). Faktor-faktor tersebut sejalan dengan temuan penelitian yang dilakukan di beberapa negara lainnya.

Masyarakat memiliki kriteria tertentu terkait parpol yang baik. Remaja di Morroco menyebutkan bahwa mereka akan memilih parpol yang dapat memenuhi janji-janji pemilu, dapat memenuhi kebutuhan masyarakat, dan memberikan peluang untuk mereka terlibat dalam politik (NDI, 2012). Haryanto dkk. (2015) juga mengutarakan konsep yang serupa. Masya-rakat cenderung akan memilih elit politik yang jujur, bertanggungjawab, tegas, kompeten, transparan, dan bijaksana.

Buruknya citra parpol dan rendahnya tingkat partisipasi politik remaja membuat penulis tertarik untuk mengkaji persepsi remaja terhadap partai politik. Selain itu, tidak banyak penelitian yang membahas persepsi pemilih pemula terhadap partai politik. Berdasarkan penelusuran peneliti di laman Google Scholar, sebagian besar penelitian cenderung membahas pemilih pemulah dalam kaitannya dengan partisipasi politik. Sehingga, penelitian ini diharapkan dapat berkontribusi secara teoritis maupun praktis terkait pemilih pemula dan politik.

Penelitian ini akan menggunakan pendekatan persepsi kontruktivis. Pendekatan ini memandang bahwa persepsi merupakan sebuah pemaknaaan terhadap realitas dengan melibatkan inferensi (Rookes \& Willson, 2000). Pendekataan ini berbeda dengan pandangan yang memandang bahwa persepsi merupakan respon secara langsung terhadap stimulus yang masuk. Pendekatan konstruktivis berpendapat bahwa individu tidak dapat langsung mempersepsi karena stimulus bersifat ambigu. Oleh karena itu, kita memerlukan pengetahuan atau pengalaman di masa lalu untuk menyelesaikan permasalahan tersebut.

Penelitian-penelitian sebelumnya dalam literatur psikologi politik juga telah menunjukkan bahwa pengetahuan politik berperan dalam mengarahkan individu terlibat dalam aksi-aksi politik, seperti ikut dalam pemilihan (Anson, 2018; McAllister, 2016). Hal ini karena pengetahuan politik dalam mendorong individu menjadi lebih tertarik masuk kedalam informasi-informasi politik dan kemudian meningkatkan pengetahuan politiknya (Henn \& Foard, 2014). Pengetahuan politik yang diperoleh dari informasi-informasi politik itulah yang kemudian dapat menginformasikan kepada individu tentang kegunaan keterlibatan dalam diskusi politik (David, 2009), dan mendorong individu untuk melakukan pencarian informasi tambahan tentang isu politik tertentu (Cowen, 2005).

Berdasarkan penjelasan teori tersebut, dapat disimpulkan bahwa ada dua faktor utama yang berperan penting dalam memahami partisipasi politik, yaitu persepsi dan pengetahuan politik. Oleh karena itu, pada penelitian ini, sebagai studi pendahulu, peneliti ingin mengkaji bagaimana persepsi dan pengetahuan remaja tentang politik, khususnya partai politik. Penulis merumuskan pertanyaan 
penelitian ini adalah: (1) bagaimanakah pengetahuan pemilih pemula terkait partai politik? (2) bagaimanakah persepsi pemilih pemula terhadap partai politik?

\section{Metode Penelitian}

Penelitian ini menggunakan metode kualitatif. Yin menyebutkan ada lima karakteristik metode kualitatif yaitu: 1) mengkaji kehidupan individu dalam dunia nyata (bukan dalam lab); 2) metode ini dapat menghasilkan representasi dari perspektif individu; 3) melibatkan konteks dari kehidupan individu; 4) menggunakan berbagai sumber (Yin, 2013). Neuman menjelaskan bahwa metode kualitatif ditandai dengan: 1) dunia merupakan hasil konstruksi sosial; 2) berfokus kepada interaksi; 3) mengutamakan keaslian; 4) nilai-nilai terlihat; 5) analisisnya tematis; dan 6) peneliti terlibat langsung dalam penelitian (Neuman, 2014). Penulis menggunakan metode kualitatif karena ingin melihat pemaknaan individu terhadap parpol.

Informan dari penelitian ini dipilih dengan menggunakan teknik sampel nonprobability sampling khususnya teknik purposive sample. Penulis menggunakan beberapa kriteria dalam memilih sampel yang akan digunakan yaitu: (1) berusia 16 tahun ke atas; (2) belum pernah mengikuti pemilu; (3) sedang menempuh sekolah menengah atas (SMA); (4) berdomisili di kota Bandung. Penulis memilih pemilih pemula di kota Bandung sebagai informan penelitian karena kota ini merupakan salah satu kota di Jawa Barat dengan jumlah pemilih pemula terbanyak. Jumlah informan penelitian ini adalah 20 orang dengan sebagian besar sedang menempuh pendidikan di sekolah menengah atas (SMA). Penulis menggunakan wawancara sebagai teknik pengumpulan data.

Data yang dihasilkan dari wawancara akan diproses melalui tiga tahapan yaitu: (1) data reduction; (2) data display; (3) conclucsion dan verification (Lune \& Berg, 2017). Pada tahapan pertama, data yang tidak relevan dengan pertanyaan penelitian akan dibuang. Sementara itu, data yang sudah dibersihkan akan di lakukan pengkategorian dan analisis dengan menggunakan analisis isi. Terakhir, data hasil dari analisis isi akan digunakan untuk menjabarkan hasil penelitian dengan menggunakan pendekatan deskriptif.

\section{Hasil Penelitian}

Persepsi terbentuk melalui serangkaian proses yang diawali dengan adanya stimulus informasi. Stimulus tersebut kemudian diproses menjadi pengetahuan yang digunakan sebagai landasan bagi individu dalam mempersepsi sesuatu. Oleh karena itu, pada tahapan awal penulis akan membahas pengetahuan informan terkait dengan partai politik. Pengetahuan tersebut meliputi definisi atau konsep partai politik (parpol), peran parpol dalam berdemokrasi, pemerintahan, dan untuk rakyat.

Hasil penelitian menunjukkan bahwa informan memiliki tingkat pengetahuan yang rendah. Rata-rata informan tidak memiliki pengetahuan mengenai definisi dan peran partai politik. Sebagian besar informan mampu mendefinisikan parpol meskipun mereka tidak sepenuhnya yakin dengan jawaban tersebut. Berikut dua buah contoh jawaban dari informan yang tidak begitu yakin dengan jawabannya:

"Duh, apaan ya, berat nih pertanyaannya, hmmm, apa ya, wadah untuk orang-orang untuk berpolitik". "(tertawa lagi) apa ya, apa sih kayak-organisasi yang buat ngaturngatur pemerintah".

Beberapa orang informan lainnya terlihat yakin dalam menjawab pertanyaan yang diberikan. Meskipun, jawaban tersebut tidak sepenuhnya benar. Salah seorang infoman menjawab partai politik adalah "sekelompok orang yang bekerja mengurusi urusan rakyat dan negara". Informan lainnya menjawab bahwa parpol adalah "sekumpulan orang-orang yang membela partai" dan "untuk memilih anggota DPR". 
Akademisi memiliki definisi yang beragam terkait parpol. Misalnya saja Carl Friedrich yang menyebutkan parpol sebagai sekelompok orang terorganisir dengan tujuan untuk merebut atau mempertahankan kekuasaan pemimpinnya dalam pemerintahan (Surbakti, 2010). Sementara itu, UU Nomor 2 Tahun 2008 mendefinisikan parpol sebagai:

\section{“..organisasi yang bersifat nasional dan dibentuk oleh sekelompok war- ga negara Indonesia secara suka- rela atas dasar kesamaan kehendak dan cita-cita untuk memperjuangkan dan membela kepentingan politik anggota, masyarakat, bangsa dan negara, serta memelihara keutuhan Negara Kesatuan Republik Indo- nesia”.}

Berdasarkan kedua definisi di atas, hanya enam orang informan yang dapat menjawab dengan benar. Selebihnya, lima orang informan sama sekali tidak dapat mendefinisikan apa itu parpol. Hal berbeda ditemukan ketika informan diberikan pertanyaan seputar peran parpol dalam demokrasi, pemerintahan, dan dalam kaitannya dengan rakyat.

Rata-rata tingkat pengetahuan informan terkait peran parpol dapat dikategorikan lebih tinggi bila dibandingkan dengan pengetahuan mereka tentang definisi parpol. Hal ini tergambar dari banyaknya informan yang dapat menjawab dengan jawaban yang tepat. Sebagian besar informan menyebutkan bahwa peran parpol dalam demokrasi adalah sebagai wadah untuk menampung aspirasi dan keluhan masyarakat untuk kemudian diselesaikan serta mempersipakan calon untuk dipilih dalam pemilu. Jawaban tersebut sejalan dengan tulisan yang ditulis oleh Jimly Asshiddiqi (2006).

Beliau mengungkapkan bahwa Indonesia merupakan salah satu negara yang menganut sistem demokrasi perwakilan (Asshiddiqie, 2006). Konsekuensinya adalah adanya jarak antara rakyat yang berdaulat dengan pemerintahan yang dibentuk. Oleh karena itu, parpol hadir dalam menjebatani jarak tersebut. Parpol berperan sebagai pihak yang menata atau menampung aspirasi rakyat untuk kemudian dijadikan landasan dalam pembuatan keputusan yang teratur (Asshiddiqie, 2006).

Parpol dan pemerintahan tidak dapat dipisahkan. Kedua pihak saling bahu membahu dalam membangun negara ini. Parpol melalui perwakilannya di parlemen berperan dalam mengawasi kinerja pemerintah. Selain itu, parpol juga berperan dalam menyiapkan kandidat terbaiknya untuk membantu pemerintahan dengan mengirimkan perwakilannya untuk menjadi menteri. Sebagian besar informan sudah mengetahui peran tersebut. Salah satu contohnya adalah informan yang menyebutkan bahwa parpol berperan membantu pemerintah dalam menjalankan pemerintahan.

Parpol tidak hanya berperan dalam membantu pemerintah. Akan tetapi, parpol juga berperan dalam membantu menampung aspirasi masyarakat untuk kemudian itu menjadi bahan pertimbangan bagi anggota parpol di DPR dalam merumuskan undang-undang. Informan sudah memahami peran yang diemban oleh anggota parpol. Hanya saja, ada beberapa informan yang berpendapat bahwa peran parpol seharusnya lebih dari itu seperti melayani dan mensejahterahkan rakyatnya.

Dalam kaitannya dengan rakyat, parpol juga memiliki peran berupa sebagai wadah untuk menampung aspirasi dari mereka. Peran ini sudah diketahui oleh sebagian besar informan yang menyebutkan bahwa parpol berperan dalam menampung aspirasi rakyat. Selain itu, informan juga berpendapat bahwa peran parpol juga meliputi melindungi masyarakat, menjaga keamanan masyarakat, dan mensejahterakan masyarakat. Beberapa informan ada juga yang memiliki pemahaman yang salah terkait peran parpol untuk rakyat. Misalnya, informan berpendapat bahwa peran parpol adalah mengawasi masyarakat, membantu ma- 
syarakat dalam berbagai kebutuhan hidup, dan mengelola suatu daerah.

Sebuah partai politik tidak hanya memiliki peran tetapi juga tugas, fungi, dan hak. Ada empat fungsi partai politik dalam sebuah negara berdemokrasi yaitu komunikasi politik, sosialisai politik, rekrutmen politik, dan pengatur konflik (Asshiddiqie, 2006). Firmanzah (2010) mengkategorikan fungsi parpol ke dalam dua kelompok yaitu fungsi parpol bagi pihak internal dan eksternal. Bagi pihak internal, parpol berfungsi sebagai pihak yang pembinaan, edukasi, pembekalan, kaderisasi, dan melanggengkan ideologi politik dari partai politik (Firmanzah, 2008). Sementara itu, Surbakti mengungkapkan ada beberapa fungsi parpol yaitu sosialisasi politik, rekrutmen politik, partisipasi politik, pemadu kepentingan, komunikasi politik, pengendalian konflik, dan kontrol politik (Surbakti, 2010).

Salah satu fungsi utama partai politik adalah komunikasi politik yaitu proses penyampaian pesan atau informasi politik dari pemerintah kepada rakyat maupun sebaliknya (Surbakti, 2010). Sebagian besar informan sudah mengetahui bahwa salah satu fungsi parpol adalah sebagai perantara antara pemerintah dan rakyat. Akan tetapi, beberapa informan berpendapat bahwa parpol bukanlah medium utama untuk menyampaikan aspirasi tersebut. Mereka menyebutkan media sosial dan media konvensional juga dapat menjadi perantara antara mereka dan pemerintah. Berikut beberapa contoh jawaban mereka.

"Gak juga sih, karena yang utamanya kan DPR, soalnya partai politik juga nanti masuknya kan ke DPR"

"Nggak juga. Masih banyak yang lainnya. Kayak sosmed, aspirasi rakyatnya bisa didenger di sosmed, kan bisa langsung ditujukan buat kepala pemerintahannya langsung" "Tidak, karena ada media sosial, ada wartawan, dan ada mediamedia cetak"
Fungsi parpol berikutnya adalah sosialisasi atau pendidikan politik. Parpol dituntut untuk mampu mensosialisasikan atau mengedukasi masyarakat mengenai politik baik dengan cara mengajak masyarakat bergabung di parpol ataupun tidak. Sebagian besar informan tidak mengetahui bahwa salah satu fungsi parpol adalah memberikan pendidikan politik kepada masyarakat. Lebih lanjut mereka juga tidak mengetahui bentuk pendidikan politik yang seharusnya diberikan oleh parpol.

Hal senada juga ditemukan pada pengetahuan informan tentang fungsi rekrutmen dari parpol. Setengah dari informan mengaku tidak mengetahui dan tidak pernah melihat parpol melakukan rekrutmen politik. Informan mengungkapkan bahwa bukti ketiadaan pendidikan politik dari parpol adalah masyarakat yang tetap tidak melek politik, dan politik hanya dipahami oleh anggota parpol. Surbakti menyebutkan bahwa rekrutmen politik merupakan seleksi dan pemilihan atau pengangkatan seseorang atau sekelompok orang untuk menjalankan sejumlah peranan dalam politik (Surbakti, 2010). Salah seorang informan mencontohkan, rekrutmen politik itu dapat berupa rekrutmen artis untuk menjadi anggota parpol.

Sementara itu, informan memiliki tingkat pengetahuan yang tinggi terkait fungsi parpol dalam menangani konflik di masyarakat. Meskipun mereka merasa tidak begitu yakin dengan jawaban yang dilontarkan. Mereka menyebutkan bahwa penanganan konflik merupakan tanggungjawab bersama sehingga parpol juga harus terlibat. Selain itu, salah seorang informan juga menyebutkan bahwa fungsi tersebut ada karena parpol memiliki tanggungjawab untuk melindungi dan menciptakan keamanan dan ketentraman di masyarakat.

Pengetahuan informan terkait definisi, peranan, dan fungsi parpol di atas membentuk persepsi mereka terhadap parpol. Hal tersebut karena persepsi adalah proses pengkategorian dan penginterpretasian kesan-kesan atau stimulus guna 
memberikan arti terhadap lingkungan (Robins \& Judge, 2008). Secara garis besar, informan memiliki persepsi negatif terhadap partai politik.

Informan mempersepsikan partai politik sebagai organisasi untuk mendapatkan uang, korupsi, kegiatannya hanya melakukan kampanye, dan sering disalahgunakan. Selain itu, partai politik dipersepsikan sebagai organisasi yang sering melakukan pencitraan.

Parpol juga dipandang tidak dapat menjalankan perannya sebagai medium penyaluran aspirasi masyarakat. Informan menyebutkan parpol belum maksimal menyalurkan karena masih banyak masyarakat yang belum bisa menyalurkan aspirasinya ke parpol. Alasan lainnya adalah tidak adanya respon terhadap aspirasi yang disampaikan, parpol yang masih mementingkan diri sendiri, dan masyarakat lebih memilih aksi demonstrasi untuk menyampaikan aspirasi mereka.

Fungsi lainnya yang juga dinilai tidak berjalan baik oleh informan adalah fungsi pendidikan politik, rekrutmen, dan konflik. Informan berpendapat bahwa parpol hanya memberikan sosialisai atau pendidikan politik hanya disaat menjelang pemilu. Selain itu, parpol dinilai selama ini lebih sering memberikan bantuan daripada membeirkan pendidikan politik. Hal ini memperkuat penelitian sebelumnya yang dilakukan di Provinsi Banten. Remaja tersebut berpendapat bahwa parpol tidak dapat menjalankan fungsinya dalam memberikan pendidikan politik karena parpol melakukan politik uang (Hermawan, 2011).

Persepsi negatif tidak hanya terkait dengan parpol yang tidak dapat menjalankan fungsinya dengan baik. Parpol juga dipersepsikan negatif oleh informan terkait dengan kinerja mereka yang tidak dapat mewakili rakyat dan bergerak untuk kesejahteraan rakyat. Informan berpendapat bahwa parpol hanya bekerja untuk kepentingannya sendiri.

Partai politik sebaiknya mulai menyadari dan mengatasi persepsi negatif yang melekat pada mereka. Terutama, persepsi tersebut berasal dari pemilih pemula yang merupakan penerus bangsa. Hal ini akan mengakibatkan pemilih pemula bersikap apatis terhadap politik. Selain itu, pemuda juga akan cenderung menentang kebijakan pemerintah dan tidak mengakui pemerintah yang berkuasa (Hermawan, 2011).

\section{Diskusi}

Hasil penelitian menunjukkan bahwa pemilih pemula memiliki pengetahuan yang rendah terkait partai politik. Informan memiliki pengetahuan yang rendah terkait definisi dan fungsi partai politik. Sementara itu, mereka memiliki pengetahuan yang tinggi terkait peran partai politik bagi pemerintahan dan rakyat. Rendahnya pengetahuan informan terkait partai politik sejalan dengan beberapa penelitian terdahulu yang menyebutkan bahwa

Ada beberapa faktor yang menyebabkan masyarakat memiliki persepsi negatif terhadap elit politik yaitu: (1) kebohongan; (2) korupsi; (3) rendahnya kepedulian terhadap sesama; (4) tidak transparan; (5) penyalahgunaan kekuasaan; (6) ketidaktegasan (Haryanto dkk., 2015). Penelitian ini juga menemukan bahwa faktor-faktor tersebut (khususnya korupsi, perebutan kekuasaan, dan hanya mementingkan golongan) juga menjadi penyebab pemilih pemula mempersepsi negatif partai politik.

Faktor-faktor di atas merupakan pengetahuan awal yang dimiliki oleh pemilih pemula terkait partai politik. Pengetahuan tersebut beserta ekspektasi yang diharapkan menjadi komponen yang penting dalam proses mempersepsi. Hal ini sejalan seperti yang diungkapkan oleh Rookes dan Willson (2000) bahwa pengetahuan, pengalaman di masa lalu, dan ekspektasi berpengaruh terhadap persepsi. Pemilih pemula memiliki pengetahuan yang rendah tentang partai politik dan pengetahuan tersebut cenderung berisi informasi negatif. Misalnya, partai politik itu organisasi yang mengurus kepentingan partai, kegiatannya hanya 
kampanye, korupsi, dan berebut kursi. Suprojo (2013) dalam penelitiannya juga menemukan bahwa informasi politik yang selalu disebarkan oleh media bersifat negatif seperti perebutan kekuasaan dan saling menjatuhkan lawan. Lebih lanjut, Suprojo menyebutkan media jarang memberitakan hal-hal positif dari politik sehingga pemilih pemula cenderung bersikap apatis terhadap politik.

Persepsi negatif juga disebabkan oleh ekspektasi yang tidak sesuai dengan realitas. Misalnya saja, pemilih pemula mengharapkan bahwa partai politik seharusnya menjadi saluran aspirasi rakyat. Faktanya, pemilih pemula berpendapat bahwa partai politik tidak maksimal menjadi saluran aspirasi rakyat. Contoh lainnya adalah pemilih pemula berharap bahwa partai politik dapat memperjuangkan kepentingan rakayat. Akan tetapi, partai politik saat ini hanya sibuk mengurus kepentingan golongan mereka. Temuan penelitian di atas sejalan dan memperkuat teori perceptual set yang diperkenalkan oleh Allport yang menyebutkan bahwa pengetahuan dan ekspektasi mempengaruhi bagaimana individu mempersepsi atau memaknai sebuah realitas (Rookes \& Willson, 2000).

Penelitian ini tidak terlepas dari kekurangan yang dapat dijadikan saran untuk penelitian kedepannya. Penulis menyarankan agar penelitian kedepannya membahas mengenai perbedaan individu dalam mempersepsi partai politik. Perbedaan tersebut dapat dilihat dari konteks individual dan psikologis dan sosial dan budaya. Hal ini penting dilakukan guna memperkaya dan memperdalam persepsi remaja terhadap partai politik.

\section{Kesimpulan}

Pemilih pemula merupakan salah satu pemilih dengan jumlah terbanyak di Indonesia. Mereka selalu antusias untuk memanfaatkan hak pilihnya. Hanya saja antusiasme itu jarang diikuti dengan pengetahuan politik yang memadai. Hal ini sangat berbahaya karena mereka dapat dimanfaatkan oleh pihak-pihak tertentu.
Hasil penelitian ini menunjukkan bahwa pemilih pemula tidak memiliki pengetahuan yang mendalam mengenai konsep, peran, dan fungsi partai politik. Temuan ini sejalan dengan penelitian yang dilakukan oleh National Democratic Institute (2012) di Maroco, Hermawan (2011) di Banten dan Suprojo (2013) di Malang. Ketiga penelitian tersebut menyebutkan bahwa remaja memiliki pengetahuan yang rendah terkait partai politik.

Pengetahuan tersebut ikut mempengaruhi persepsi mereka terhadap partai politik. Pemilih pemula cenderung mempersepsi partai politik sebagai organisasi untuk mendapatkan uang, korupsi, kegiatannya hanya melakukan kampanye, sering disalahgunakan, dan sering melakukan pencitraan. Selain itu, parpol juga dipersepsi tidak dapat menjalankan peran dan fungsinya dengan maksimal. Salah satunya adalah parpol tidak dapat menjalankan perannya sebagai media yang dapat menampung aspirasi masyarakat. Mereka berpendapat bahwa parpol lebih mementingkan kepentingan pribadinya.

Penelitian ini tidak terlepas dari kekurangannya. Oleh karena itu, penulis menyarankan bahwa untuk kedepannya, penelitian menggunakan informan dengan jumlah lebih besar dan latar belakang yang berbeda. Selain itu, penelitian selanjutnya sebaiknya juga membahas pengaruh perbedaan individu dalam mempersepsi partai politik.

\section{Daftar Pustaka}

Anson, I. G. (2018). Partisanship, Political Knowledge, and the Dunning-Kruger Effect. Political Psychology. doi: 10.1111/pops. 12490

Asshiddiqie, J. (2006). Parpol dan Pemilu Sebagai Instrumen Demokrasi. Konstitusi, 3(4), 6-27.

Cowen, T. (2005). Self-deception as the root of political failure. Public Choice, 124(3), 437-451. doi 10.1007/s11127-005-2058-y ·

David, C. C. (2009). Learning political information from the news: A closer 
look at the role of motivation. Journal of Communication, 59(2), 243-261. doi: 10.1111/j.1460-2466.2009.01414.x

Firmanzah. (2008). Mengelola partai politik: komunikasi dan positioning ideologi politik di era demokrasi. Yayasan Obor Indonesia. Retrieved from https://books.google.co.id

Hanan, D. (2015). Parpol dan Persepsi Publik. Kompas.com. Retrieved March 21, 2018, from https://nasional.kompas. com

Haryanto, H. C., Rahmania, T., Mubarok, A. R., Dopo, A. B., Fauzi, H., \& Fajri, E. (2015). Bagaimanakah Persepsi Keterpercayaan Masyarakat terhadap Elit Politik? 42(3), 243-258.

Henn, M., Weinstein, M., \& Forrest, S. (2005). Uninterested youth? Young people's attitudes towards party politics in Britain. Political Studies, 53(3), 556-578. doi: 10.1111/j.14679248.2005.00544.x

Henn, M., Foard, N. (2014) Social differentiation in young people's political participation: the impact of social and educational factors on youth political engagement. Journal of Youth Studies, 17(3), 360-380, doi: 10.1080/13676261.2013.830704

Hermawan, A. A. (2011). Persepsi Pemuda Terhadap Partai Politik Nasional Peserta Pemilu 2014 dan Implikasinya Terhadap Ketahanan Politik Wilayah (Studi Pada KNPI Provinsi Banten). Jurnal Ketahanan Nasional, 20(3), 1-13. Retrieved from https://journal.ugm.ac.id

Hidayah, C., Gunawan, I. K., \& Budiman. (2017). Partisipasi politik pemilih pemula dalam Pemilukada Kutai Kartanegara tahun 2015 di Kecamatan Samboja. eJournal IImu Pemerintahan 5(4), 1693-1704.

Ihsanuddin. (2018). Survei LSI: 5 Partai di DPR Terancam Tak Punya Kursi Lagi. Kompas.com. Retrieved March 26, 2018, from https://nasional.kompas.com

Katz, R. S., \& Crotty, W. J. (2006). Handbook of Party Politics - Google Buku. SAGE. Retrieved from https://books.google.co.id

Lune, H., \& Berg, B. L. (2017). Qualitative research methods for the social sciences.

Mack, C. S. (2010). When political parties die: a cross-national analysis of disalignment and realignment. Praeger. Retrieved from https://books.google.co.id

McAllister,I. (2016). Internet use, political knowledge and youth electoral participation in Australia. Journal of Youth Studies. 19(9), 1220 1236. doi: 10.1080/13676261.2016.1154936

MedNet. (2014). Youth Participation in Politics. Retrieved from http://edu.oxfam.it

NDI. (2012). Youth Perceptions in Morocco: Political Parties in the Wake of Legislative Elections Findings from Qualitative Research in Morocco Conducted in March and April 2012. Washington. Retrieved from https://www.ndi.org

Neuman, W. L. (2014). Social Research Methods: Qualitative and Quantitative Approaches. Relevance of social research (Vol. 8). doi: $10.2307 / 3211488$

O'Toole, T., Lister, M., Marsh, D., Jones, S., \& McDonagh, A. (2003). Tuning out or left out? Participation and nonparticipation among young people. Contemporary Politics, 9(1), 45-61. doi: 10.1080/1356977032000072477

Parry, G., Moyser, G., \& Day, N. (1992). Political participation and democracy in Britain. Cambridge University Press.

Pirie, M. \& Worcester, R. (2000), The Big Turn-Off: Attitudes of Young people to Government, Citizenship and Community, London: Adam Smith Institute.

Robins, S. P., \& Judge, T. A. (2008). Perilaku Organisasi edisi 12. Jakarta: Salemba Empat.

Rookes, P., \& Willson, J. (2000). Perception: Theory, Development and Organisation. London: Routledge. Retrieved from https://books.google.com

Suprojo, A. (2013). Analisis Tingkat 
Partisipasi Pemilih Pemula Pasca Ketetapan Komisi Pemilihan Unum Tentang 10 Partai Peserta Pemilu 2014 Dalam Pembangunan Politik Masyarakat. Reformasi, 3(1), 1-9. Retrieved from https://jurnal.unitri.ac.id Surbakti, R. (2010). Memahami IImu Politik. Jakarta: Grasindo.
Tamanna, M. (2018). The Political perception of youth: Where are we heading to?. Jurnal Akta, 5(5), 743750.

Yin, R. K. (2013). Qualitative Research from Start to Finish (Vol. 53). The Guidford Press. doi: 10.1017/CBO9781107415324.004 